\title{
Behind the screen: Understanding national support for a foreign investment screening mechanism in the European Union
}

\author{
Zenobia T. Chan ${ }^{1}$ (D) . Sophie Meunier ${ }^{2}$ (D)
}

Accepted: 26 May 2021 / Published online: 13 July 2021

(c) The Author(s), under exclusive licence to Springer Science+Business Media, LLC, part of Springer Nature 2021

\begin{abstract}
What determines national preferences for institutionalizing foreign direct investment (FDI) screening? Over the past decade, advanced economies worldwide have tightened their national investment screening mechanisms (ISMs). In March 2019, the European Union (EU) adopted its first common FDI screening framework. This article explores variations in Member State preferences for the creation and nature of a pan-European screening framework. Based on extensive interviews with high-level EU and country officials involved in the negotiation process, and using a unique measure of national support for the EU-wide ISM created through the first-ever elite survey on this subject matter, we find that countries with higher technological levels were more supportive of FDI screening due to concerns over unreciprocated technological transfer. We also show the effects of Chinese FDI on country-level support for FDI screening sector-dependent. We found no evidence that total Chinese FDI predicts preferences for ISM. Instead, countries with high levels of Chinese FDI in strategic sectors are more likely to support the ISM, while those with high levels of Chinese investment in low-tech sectors tend to oppose screening. Our overall findings suggest that EU investment screening, and national-level screening in general, might become more restrictive in the future, especially in light of the COVID-19 pandemic.
\end{abstract}

Keywords China $\cdot$ Europe $\cdot$ European Union · FDI · Investment $\cdot$ Screening

Responsible editor: Axel Dreher

Author contributions to conceptualization and research design: Z.C. (20\%), S.M. (80\%); statistical analysis: Z.C. (100\%); writing: Z.C. (30\%), S.M. (70\%). The order of authors is chosen alphabetically.

Zenobia T. Chan

zeno@princeton.edu

Extended author information available on the last page of the article 
JEL Classification F21 International Investment • Long-Term Capital Movements • F23 Multinational Firms • International Business • F52 National Security • Economic Nationalism · F55 International Institutional Arrangements

"We are not naïve free traders. Europe must always defend its strategic interests. This is why today we are proposing a new EU framework for investment screening," declared Jean-Claude Juncker, President of the European Commission, in his 2017 State of the Union address. ${ }^{1}$ With this speech, the European Union (EU) formally launched a policy process for screening inbound Foreign Direct Investment (FDI) in Europe. In March 2019, joining other advanced economies like the United States, Canada, and Australia, the EU adopted its first common screening framework for foreign investments.

Global FDI totaled US\$1.39 trillion in 2019 (UNCTAD, 2020), representing an essential type of flow in international political economy (IPE) that can foster technological transfer, economic growth, and development (e.g. Alfaro et al., 2010; Blomström et al., 1994; Knell \& Radošević, 2000; Romer, 1993; Tang et al., 2008). Around the turn of the twenty-first century, most countries have replaced FDI restrictions with FDI incentives (Pandya, 2016: 459), with democratization as a main contributing factor to this increased FDI openness around the world (Pandya, 2014). Yet this new policy adopted by the EU, comprised of 28 democracies that were among the world's most open to FDI back then (see OECD Directorate for Financial \& Enterprise Affairs, 2020), seems to challenge such premises. Although the EU eventually created a common investment screening framework, Member States had initially held various opinions on such a framework. What explains national variations in EU Member States' initial preferences for a common investment screening framework?

The 28 EU Member States' simultaneous negotiation process for one supranational screening framework provides a unique opportunity to better understand the determinants behind national preferences for institutionalizing FDI screening. ${ }^{2}$ This paper contributes to the emerging IPE literature on Investment Screening Mechanisms (ISM) (e.g. Anwar, 2012; Bauerle Danzman \& Meunier, 2021; Lenihan, 2018; Schill, 2019; Tingley et al., 2015), as well as the recent literature in EU studies assessing and interpreting the transfer of competence of FDI policy to the supranational EU level (Basedow, 2017; Meunier, 2017).

Based on extensive interviews with senior officials at both the EU and Member State levels, we examine the national security and economic rationales for initial individual country support for a collective European screening mechanism at a time of surging Chinese direct investment in Europe. We also develop a unique measure of countries' initial support for the EU-wide FDI screening mechanism created

\footnotetext{
1 Jean-Claude Juncker (2017). State of the Union Address 2017. Speech. Brussels: European Commission, September 13. https://ec.europa.eu/commission/presscorner/detail/en/SPEECH_17_3165.

2 The negotiations started in 2017, before Brexit took effect.
} 
through the first-ever elite survey on this subject matter. We find that countries with higher technological levels are more supportive of the institutionalization of a supranational ISM due to their concerns over unreciprocated technological transfer. We also find the effects of Chinese investment sector-specific. Aggregate Chinese inwards FDI does not predict national preferences for the EU ISM. Instead, highlevel policymakers suggested that increased levels of FDI from China in strategic sectors were driving their countries' decision to step up screening of FDI at the EU level. In contrast, countries where the majority of Chinese-and Russian-investment is in mostly "innocuous" industries, like real estate, tend to oppose the EU screening mechanism. Our overall findings suggest that EU investment screening, and national-level screening in general, might become more restrictive in the future, especially in light of the COVID-19 pandemic.

The paper teases out the major determinants of EU Member States' support for the FDI screening mechanism. We begin by surveying existing research on the determinants of FDI openness and the recent proliferation of ISMs worldwide. Next, we present the new EU screening framework introduced in 2019. In Sect. 3, we process-trace how the simultaneous institutional transfer of competence over FDI policy to the EU level and the surge of Chinese direct investment in Europe generated demands for the creation of the common investment screening policy in the EU. In Sect. 4, we introduce an index of national preferences for FDI screening based on our elite survey of senior officials at both the EU and national levels. Section 5 presents our quantitative analysis of how technological intensity and reliance on FDI from China shape a country's support for FDI screening. We discuss these findings in Sect. 6 and argue that the most important explanatory variable for support for a screening mechanism is the technological intensity of the investment assets in the host country. We conclude with future avenues for research and the implications of the findings for countries outside the EU in the COVID-19 pandemic and post-pandemic era.

\section{What determines support for FDI screening?}

An important strand of IPE literature studying the determinants of countries' FDI openness emerged in the past two decades (for a review, see Pandya, 2016). This body of literature provides evidence that FDI openness is largely a result of rational choices by different players in the world economy.

On the demand side, policymakers reduce restrictions on FDI in recognition of the potential benefits of opening up to foreign investment, including knowledge transfer, technological spillovers, and tax revenue (Kobrin, 2005). Democratization has been a driving force behind liberalization of FDI as workers who benefit from unrestricted FDI can exert political influence for greater openness to FDI (Pandya, 2010). Earlier research indicates that skilled workers whose incomes are more likely to increase with FDI tend to support FDI (Pandya, 2010). This line of reasoning makes the case of the EU FDI screening mechanism especially puzzling: in the wake of a decade-long, post-recession drive to encourage FDI, why would several democracies in the then 28-country bloc impose new restrictions 
on FDI? Recent evidence suggests more nuanced dynamics on the effects of democracy on FDI openness that might explain this puzzle. Low-skilled workers who are more likely to be adversely affected by FDI tend to support restrictions on foreign investment and may leverage unionized power to maintain or impose such restrictions (Owen, 2013).

Another explanation, focused on elites, argues that it is domestic firms, rather than mass publics, that drive shifts in investment policy (Bauerle Danzman, 2019). When politically powerful indigenous businesses face substantial and rising financing constraints, they tend to support openness to FDI because foreign investors are a source of scarce financing. If, however, local credit conditions are relatively loose, domestic firms may prefer to limit FDI because inward investment generates increased competition in product and labor markets (Bauerle Danzman, 2020).

On the supply side, foreign investors respond to the government's preferences for different types of investment, with pro-capital governments tending to attract laborsubstituting investment and pro-labor ones tending to encourage labor-intensive investment (Pinto \& Pinto, 2008). Foreign investors and firms originating from the same country often organize national investor associations to lobby their home government to pressure the FDI recipient governments for protecting their investment abroad from being expropriated (Wellhausen, 2014).

Even though existing findings suggest FDI to be conducive to technological transfer, economic growth, higher wages, and development under certain conditions (e.g. Alfaro et al., 2010; Basu et al., 2003; Bitzer \& Kerekes, 2008; Blomström et al., 1994; Borensztein et al., 1998; Knell \& Radošević, 2000; Romer, 1993; Tang et al., 2008), FDI can indeed adversely affect a country. Evidence from existing research has shown that multinational corporations (MNCs) and the FDI they draw in exacerbate income inequality (e.g. Basu \& Guariglia, 2007; Figini \& Görg, 1999, 2011; Herzer et al., 2014; Taylor \& Driffield, 2005; Wei et al., 2009). Other studies have found that FDI can increase volatility in labor markets (Scheve \& Slaughter, 2004; cf. Buch \& Lipponer, 2010) and, therefore, be opposed by organized labor under certain conditions (Owen, 2015). FDI also creates concerns over unreciprocated technological transfer (Chilton et al., 2020).

While these adverse consequences of openness to foreign investment may give rise to restrictions on inward FDI in a given country, the literature studying the determinants of investment screening is underdeveloped. Controversies over acquisitions by foreign investors have given rise to a few studies examining national security concerns stemming from FDI openness, and the resulting debates and national responses, mostly in the U.S. context. For example, Kang (1997) argues that the establishment and subsequent strengthening of the Committee on Foreign Investment in the United States (CFIUS) was a response to public unease about acquisitions in the U.S. by foreign investors. Bauerle Danzman (2021) emphasizes how the narrow focus of CFIUS on national security rather than broader policy concerns, and the preference for mitigating rather than blocking transactions, are evidence that investment screening provides the U.S. government with 
circumscribed legal processes and tools to maintain minimally necessary national security guardrails in the context of open investment climates.

Although national security has often been cited as the reason to block foreign acquisitions, both academic and policy-oriented researchers have argued that investment screening results from a combination of commercial, economic, institutional, and national security factors. In one of the most comprehensive studies on FDI screening to date, Lenihan (2018) argues that states leverage their ability to intervene into incoming foreign investment as a non-military tool of statecraft for internal balancing, preserving or enhancing economic and/or military capability domestically. Indeed, commercial interests can substantially shape politicians' support for increased FDI screening, such as in the highprofile cases of the Chinese state-owned CNOOC's proposal to acquire Unocal in 2005 and Dubai Ports World's bid for the Peninsular and Oriental Steam Navigation in 2006 (Graham \& Marchick, 2006: chap. 4; Frye \& Pinto, 2009). Similarly, Canes-Wrone et al. (2020) show that opposition to specific transactions often originate from a district different from the one in which the investment is located, suggesting commercial motives behind FDI scrutiny. Support for stricter FDI screening can also be shaped by institutional factors. Especially in federal or quasi-federal systems, which level of government possesses the authority over the regulation of inward FDI often allows different interests to prevail in the decision-making process (Canes-Wrone et al., 2020). A recent study by Bauerle Danzman and Meunier (2021) examines how the COVID-19 pandemic has accelerated the strengthening of ISMs in OECD countries.

Moreover, the recent proliferation and tightening of FDI screening mechanisms in many advanced economies fits within broader patterns of globalization backlash and structural changes to trade policy. The growth of global value chains, which has dispersed production (and producers) around the world, has acted as a constraint against protectionist interests. But this has also been accompanied by an increasingly popular backlash against globalization and calls for economic nationalism and industrial policy (Dür et al., 2020). In the EU, the past decade has been characterized by a growing politicization of trade policy (Leblond \& Viju-Miljusevic, 2019; Meunier \& Czesana, 2019). Growing politicization, coupled with the blurring of economy and security, has led to the "securitization" (Roberts et al., 2019) and "geopoliticization" (Meunier \& Nicolaidis, 2019) of trade and investment policy in many regions, especially in the EU. These calls to weaponize international economic policy have become particularly salient in Europe and the U.S. as a result of the rise of China and other countries whose national practices introduce "market distortions" (Lang, 2019). It is in this broader geoeconomic context that the recent proliferation and tightening of ISMs must be understood.

However, whether ISMs are indeed economic nationalist instruments with protectionist effects in the long run remains to be seen. Schill (2019) argues for the existence of an "investment screening paradox." Although a new screening mechanism restricts inward investment flows in the short run, the mechanism may paradoxically lead to further liberalization of investment by providing bargaining leverage in future negotiations (Schill, 2019). 


\section{The regulation on investment screening}

The regulation adopted by the Council and European Parliament in March 2019 (Regulation 2019/452) provides a first step towards mandating foreign investment review in the EU, ${ }^{3}$ though it is by no means an independent screening mechanism at the European level. For the first time this regulation creates some procedures for foreign investment into the Single Market to be reviewed by entities other than the host country and for Member States to recognize that some investments may be politically problematic, but the ultimate decision to accept or reject the investment lies with the host country.

The main feature of the new EU investment screening framework is the creation of a cooperation mechanism between the Member States and the Commission to exchange information and raise concerns about specific transactions that "may threaten security or public order," mostly for investments in critical technologies and infrastructure. Screening is not allowable on economic grounds, unlike in countries, such as Canada, that include a "net benefits" test. The new framework applies to any foreign direct investment, whether greenfield (involving the creation of a new company or establishment) or mergers and acquisitions (involving a transfer of ownership or assets). It does not apply to portfolio investments, though the Regulation does not establish quantitative criteria for the delimitation of portfolio investment and FDI (European Commission, 2020b).

The regulation includes an indicative list of factors to be weighed by Member States when screening transactions for their implications on national security and public order. ${ }^{4}$ These non-exhaustive factors include effects on critical infrastructure, dual-use technologies, the security of supply of critical inputs, and the ability to control information and access personal data (Article 4). The regulation directs Member States to implement transparent procedures with clear guidelines for triggering a review, to adhere to a review timeline, and to "give due consideration to the comments of the other Member States" (Article 6). The regulation also requires Member States to inform the Commission and other Member States of some transactions and lists the information to be provided, such as ownership structure of the investor and approximate value of the investment (Article 9). The new framework also imposes mandatory annual reporting requirements for the Member States (Article 5).

Moreover, the regulation gives the Commission unilateral authority to conduct its own screening on grounds of "security and public order" for investments that affect a project or program of interest to the whole EU-such as Galileo and Horizon 2020 - and it may issue non-binding opinions (Article 8). Any sector

\footnotetext{
3 European Parliament and Council of the European Union (2019). "Regulation (EU) 2019/452 of the European Parliament and of the Council of 19 March 2019 Establishing a Framework for the Screening of Foreign Direct Investments into the Union." Official Journal of the European Union (LI 79): 1-14. http://data.europa.eu/eli/reg/2019/452/oj.

4 See European Parliament and Council of the European Union (2019). "Regulation (EU) 2019/452 of the European Parliament and of the Council of 19 March 2019 Establishing a Framework for the Screening of Foreign Direct Investments into the Union." Official Journal of the European Union (LI 79): 1-14. http://data.europa.eu/eli/reg/2019/452/oj.
} 
falls under the scope of the new legislation, but the Regulation highlights in particular critical infrastructure (energy, transport, communications, data, space and financial industry), critical technologies (robotics, semiconductors and artificial intelligence), and personal data.

The new framework, however, falls short of a binding, supranational mechanism. To be sure, the cooperation highlighted in the Regulation is mandatory. But the EU is a long way from the implementation of a European version of CFIUS. Indeed, talking about a single screening mechanism is a misnomer. Rather, the novel EU mechanism is more a framework setting minimum standards for the Members States' screening mechanisms and establishing a cooperation mechanism between Member States and the Commission. The new framework is meant to complement national mechanisms, rather than replacing or superseding them.

Compared to advanced industrialized countries with investment screening procedures, the EU mechanism is weak. First and foremost, the mechanism is nonbinding. Moreover, the new policy does not oblige Member States to have a national investment screening in place, although the Commission strongly encouraged Member States to do so in March 2020 at the beginning of the COVID-19 pandemic (European Commission, 2020c). Most importantly, the regulation does not create a centralized authority with the ultimate responsibility to block a transaction. Unlike the U.S., Canadian or Australian mechanisms, there is no investment review board. While the Commission has the authority to review transactions, it is not empowered to block or suspend them. Rather, Member States retain the last word whether a specific transaction should be allowed or not in their territories. The contours of the new policy will become clearer-and new controversies may arise-once the policy has been tested after its implementation in October 2020. This might come, for instance, by learning from existing mechanisms in other countries when implementing the new European framework and by building expert capacity inside the Commission.

\section{A resurgence of FDI restrictiveness in Europe?}

To understand the commercial, institutional, and national security drivers of the EU FDI screening mechanism, we process-trace the institutional transfer of competence over FDI policy operated by the Lisbon Treaty in 2009 and the rapid surge in Chinese FDI into Europe in the 2010s. These two phenomena, though unrelated at first, converged into demands for the supranationalization of FDI screening by 2017 and the eventual creation of the EU FDI screening framework in 2019.

\subsection{Competence transfer over FDI policy to the EU}

A precondition for envisioning a common FDI screening mechanism at the EU level was for foreign investment policy to be indeed a supranational competence. For the first five decades of European integration, the policies governing FDI remained 


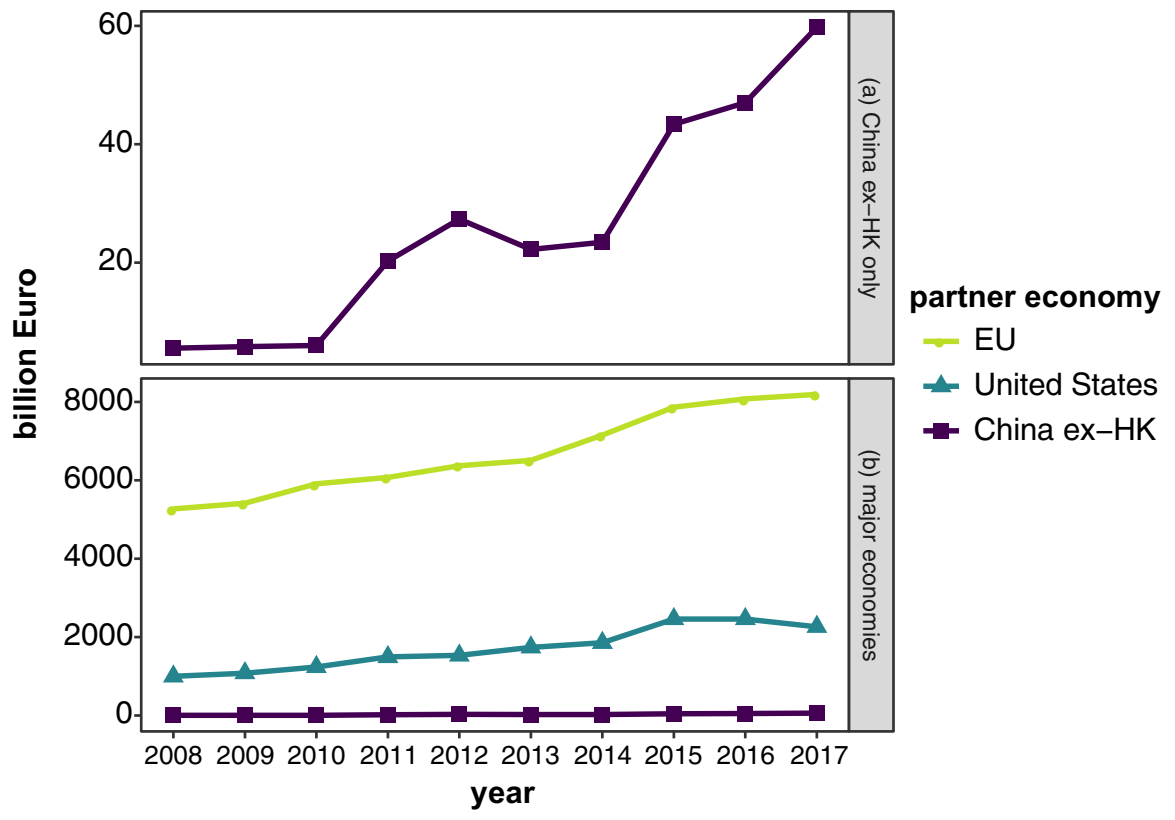

Fig. 1 Total Net Inward FDI Stocks of the European Union from China (excluding Hong Kong) and Selected Economies, 2008-2017. Data in 2012 and before include the 27 EU Member States at that time, whereas data from 2013 onwards include the 28 Member States

exclusively the responsibility of individual Member States. With goods and services flowing freely throughout the EU Single Market, the absence of a common ISM meant that a foreign investor could be rejected by Member State $A$ according to its own national screening procedures, then see its transaction accepted by Member State $B$, and then circulate freely the products made in Member State $B$ back to Member State $A$. The functional need for a common screening mechanism was, therefore, apparent, but there was no legal basis to do so.

The Lisbon Treaty, which came into force in December 2009, formally transferred the competence over FDI to the EU level by folding "foreign direct investment" under Article 207 dealing with the common commercial policy. ${ }^{5}$ However, since the competence transfer had not been debated beforehand, and since the legal wording was so vague, an inter-institutional fight over the exact nature of the competence transfer erupted in the years following the implementation of the Treaty (Basedow, 2017; Bungenberg et al., 2011; Meunier, 2017). Many Member States tried to limit the EU's newfound power over FDI policy, forcing the Court of Justice of the European Union to adjudicate on the competence issue in Opinion 2/15 about the EU-Singapore free trade agreement rendered in 2017 and in Opinion 1/17 on the

\footnotetext{
${ }^{5}$ European Union (2007). Treaty of Lisbon Amending the Treaty on European Union and the Treaty Establishing the European Community. Treaty full-text. Brussels: European Union, December 13. https:// eur-lex.europa.eu/legal-content/EN/TXT/?uri=celex\%3A12007L\%2FTXT.
} 
Comprehensive Economic and Trade Agreement (CETA) between the EU and Canada rendered in 2019. The process through which the EU-wide screening mechanism for foreign investments emerged can only be understood in the context of this Member State-EU struggle over competence (Schill, 2019). For most Member States, at least initially, the screening discussion was perceived as yet another power grab by the EU. However, for the European Commission, the EU FDI screening mechanism was a response to both a functional and an institutional imperative.

\subsection{Surge of Chinese direct investment into Europe}

At the time of the competence transfer to the EU and subsequent inter-institutional fight, Chinese investment in the EU seemingly was proliferating, yet it grew from a very low base and has in fact remained only a modest proportion of all foreign investment in the EU (see Fig. 1). Albeit initially unrelated to the FDI competence transfer, this surge of Chinese FDI in the EU soon became both the salient commercial and national security rationales for the creation of the EU FDI screening framework.

The proliferation of Chinese investment in the EU was the response to an injunction by the Chinese government to "go out" in 1998 as well as the Chinese government's launching of "One-Belt, One Road", later the "Belt and Road Initiative", in 2013 and the "Made in China 2025" Initiative (Chaisse, 2019; Jones \& Zeng, 2019; Wübbeke et al., 2016; Zeng, 2019). Chinese companies have invested since then in acquisitions and new projects around the world, first in countries with raw materials and primary resources, before turning to advanced industrialized economies in Europe and North American at the end of 2009 (Blanchard \& Zeng, 2019). Barely existent in the late 2000s, Chinese investment was growing exponentially in the early 2010s and reached a record high flow of nearly $€ 36$ billion in 2016 - almost double the total 2015 flows. Even though Chinese investment in the EU has shrunk since 2017, the drop has been less pronounced than in the U.S, where Chinese FDI has plummeted spectacularly in the same period. Despite this overall decline, Chinese investment increased in several EU countries in 2018: compared to 2017, Chinese acquisitions were up, for instance, $186 \%$ in Sweden ( $\$ 4.05$ billion), $162 \%$ in Spain ( $\$ 1.17$ billion), $86 \%$ in France ( $\$ 1.83$ billion), and 34\% in Germany ( $\$ 2.52$ billion) (Baker McKenzie, 2019). Chinese outward FDI in the EU spans across all sectors, particularly in automotive, financial services, and information technology (Baker McKenzie, 2019).

Although in absolute terms, Chinese investment in Europe soared, it constitutes only a small proportion of all foreign investment in the EU (see Fig. 1). The public salience of Chinese FDI in Europe in the political and media discourse has been disproportionate compared to its actual size. That oversized salience can be explained partly by its novelty. Indeed, previous historical instances of FDI coming from a new source have stoked fears and restrictive policies in the past, such as American MNC investment in France in the 1960s and Japanese investment in the U.S. in the 1980s. "New" and "foreign" investment is politically challenging, in addition to attention-grabbing in the media, especially if the institutional and cultural distance between host and home countries is large (Meunier, 2019). 
However, there is more than novelty and rapidity of the surge to account for the heightened concerns about Chinese FDI in proportion to its actual size. It is the perception of the unique political challenges posed by such investment that has captured most attention from policy-makers in several European countries. These challenges come from the growing realization that, unlike most other investors in Europe, China is organized as an idiosyncratic nondemocratic political system, maintains state control over many investments (even private), and is not a security ally (Meunier, 2019). Some experts have voiced fears that while most Chinese investments may be profit-seeking and politically innocuous, some may have non-economic strategic objectives directed by the Chinese state, notably with the goal of acquiring advanced technology (Le Corre \& Sepulchre, 2016; Meunier, 2014; Raess, 2020).

These concerns over the strategic motives of Chinese FDI have prompted many Western economies to alter and reinforce their ISMs. In the United States, the investment review process involving the CFIUS was strengthened in 2007 through the Foreign Investment and National Security Act (FINSA) after one of the first investment attempts by a Chinese company in the U.S., the failed 2005 CNOOC acquisition of Unocal (Jackson, 2020). The scope of this review process was broadened and strengthened again in 2018 through the rare bipartisan Foreign Investment Risk Review Modernization Act (FIRRMA) (Canes-Wrone et al., 2020). In Canada, the 1985 Investment Canada Act (ICA), whose purpose is to screen foreign investments that may threaten national security, was amended in 2013, notably to extend the timeline for review and to potentially restrict investment by state-owned enterprises. In response, the controversy raised by the 2015 acquisition of the Port of Darwin by a Chinese company, Australia also tightened its own Foreign Investment Review Board (FIRB) investment screening regime in 2018.

The Lisbon Treaty equipped the EU with the legal means to create an EU-wide ISM, whereas the political challenges caused by the surge of Chinese investment into Europe provided the impetus to enact the new policy (Grieger, 2017). The first proposal for a pan-European ISM came in February 2011. Antonio Tajani, then EU Commissioner for Industry and Entrepreneurship, and Michel Barnier, then Internal Market Commissioner, wrote a joint letter to Commission President José Manuel Barroso, warning against Europe's naïveté on foreign investment and recommending the development of a supranational body to vet FDI in the EU, analogous to the CFIUS system in place in the United States, to make sure that non-EU investments in Europe are not "attempts to close down businesses after having stolen all of their "know-how", (European Commission, 2011). The majority of Commission officials, however, dismissed this proposal, on the grounds that this would be interpreted as a protectionist move, could alienate Chinese investors in Europe, and have repercussions for European investment in China. Warning against a European version of CFIUS, European Trade Commissioner Karel De Gucht cautioned against a "neither desirable nor feasible" screening system for investment at the EU level, recalling the multiple benefits of foreign investment (increased productivity, increased trade, access to capital, etc.) and reminding his fellow Europeans of the reality: "we need the money" (De Gucht, 2012). Such a system, he argued, would also enable national security considerations to be used "as a false pretense to justify the protection of vested economic interests." 
The next proposal for an EU ISM came in 2012 from the European Parliament, which had acquired more voice on trade policy as a result of the Lisbon Treaty. In part because of the challenges and growing fears triggered by the surge of Chinese FDI into Europe, the European Parliament formally asked the Commission and the Member States in May 2012 "to set up a body entrusted with the ex ante evaluation of foreign strategic investment, along the lines of the Committee on Foreign Investment in the United States (CFIUS), in order to obtain a clear picture of businesses operating and investing in the territory of the EU" (De Sarnez, 2012: 11). However, the resolution did not gain much momentum; in January 2015, citing its commitment to "ensuring that markets remain open" the Commission stated that it had no plans to maintain mechanisms to screen investments (Malmström, 2015).

Over the next few years, Chinese direct investment into Europe continued to grow rapidly. In between 2010 and 2012, Chinese FDI stocks in the EU increased by more than $300 \%$ from $€ 6.1$ billion to $€ 26.8$ billion (Malmström, 2015). Although most Member States welcomed this new development with open arms, especially in the wake of the euro crisis, the countries with the most advanced technology started to worry about the long-term implications of Chinese investment. While France had long been paradoxically at once suspicious of and encouraging towards Chinese investment, and had tightened its own national investment screening accordingly, Germany drastically changed its position on the desirability of investment screening after several controversial acquisition bids in 2016 (see Sect. 4).

The momentum for the creation of a European ISM accelerated throughout 2017. In February 2017, France, Germany, and Italy publicly sent a letter to EU Trade Commissioner Cecilia Malmström, voicing their concerns about foreign investment in technology for strategic objectives: "We are worried about the lack of reciprocity and about a possible sell-out of European expertise, which we are currently unable to combat with effective instruments" (Le Guernigou \& Thomas, 2017). Notwithstanding the inter-institutional fight over the details of EU competence over FDI, they called for the creation of EU powers to screen and block foreign takeovers. In May 2017, the Commission released a White Paper on "Harnessing Globalization," in which it suggested for the first time that it might push for a pan-European investment screening framework (European Commission, 2017).

After his election in May 2017, the new French president Emmanuel Macron vowed to fight for a "Europe that protects" and made the proposal for the creation of a pan-European ISM the centerpiece of his first European Council. In spite of support from Germany and Italy, the French proposal was rejected by the majority of the Member States, which instead preferred the vague Commission's proposal "to analyse investments from third countries in strategic sectors, while fully respecting Member States' competences” (Valero, 2017). Nevertheless, the Commission worked on a Regulation establishing a framework for screening foreign direct investment in the EU, which European Commission President Jean-Claude Juncker proposed in his State of the Union speech on September 14, 2017. ${ }^{6}$ The goal was to

\footnotetext{
6 Jean-Claude Juncker (2017). State of the Union Address 2017. Speech. Brussels: European Commission, September 13. https://ec.europa.eu/commission/presscorner/detail/en/SPEECH_17_3165.
} 
find an acceptable unified mechanism to limit threats to critical infrastructure and technologies, while keeping European countries open for foreign investment.

The goals proposed in Juncker's (2017) State of the Union speech were shared by the European Parliament, where the proposal for an EU-wide screening enjoyed wide support across the political spectrum from the outset. A supranational framework for FDI screening was pushed especially by the French Member of the European Parliament (MEP) Franck Proust, of the centre-right European People's Party (EPP), who supported more stringent investment screening rules, including the obligation for the Commission to vet specific transactions and for Member States to cooperate. ${ }^{7}$ Another vocal supporter was the German Green MEP Reinhard Bütikofer. The position of the S\&D Group (Progressive Alliance of Socialists and Democrats) was mainly shaped by the chair of the Committee on International Trade (INTA), Bernd Lange, who seemed to share the policy objectives behind FDI screening, though the S\&D position remained a bit opaque throughout the process because he also tried to trade S\&D support for FDI screening for other purposes. ${ }^{8}$

Negotiations between the Commission, the European Parliament, and the Council lasted for 14 months. During that time, the United States shared some of its experience and best practices, worried that the absence of a unified EU screening mechanism could accelerate technology transfers to China and render its own screening efforts moot (Peker, 2018). On November 20, 2018, the EU adopted its first legislation to screen foreign direct investments. It vows to protect the "essential interests" of the Member States, while simultaneously keeping the EU as "one of the most open investment regimes" in the world. ${ }^{9}$ The agreement was endorsed in December 2018 by the International Trade Committee of the European Parliament (INTA). The final text was approved massively by the European Parliament on February 13, 2019, in a vote of 500 for, 49 against, and 56 abstentions (Valero, 2019). The legislation formally entered into force on April 11, 2019 and was fully implemented eighteen months later on October 11, 2020.

When the Commission released an explanatory frequently asked questions (FAQ) memo following the adoption of the novel screening mechanism in 2019, there was little doubt left that the rise of China as a foreign investor had provided the impetus for the new policy as the first line of defense. To the question of why it was necessary to have an EU framework on FDI screening, the Commission answered: "In the past years there have been growing concerns regarding certain foreign investors seeking to acquire control of or influence in European firms whose activities have repercussions on critical technologies, infrastructure, inputs or sensitive information, putting security or public order at risk. This is especially the case when foreign investors are state owned or controlled, including through financing or other means of direction" (European Commission, 2020b).

\footnotetext{
7 Interview with a senior staffer at the European Parliament. Brussels, February 2019.

${ }^{8}$ Interview with a senior officer in the European Commission Directorate General for Trade. Online, January 2021.

${ }^{9}$ Interviews with a senior trade official at the European Commission and with a senior staffer at the European Parliament. Brussels, February 2019.
} 
Table 1 Initial National Preferences for the EU-wide Investment Screening Mechanism

\begin{tabular}{lllll}
\hline Oppose & Somewhat Oppose & Neutral & Somewhat Support & Support \\
\hline Cyprus & Belgium & Bulgaria & Denmark & Austria \\
Estonia & Czechia & Croatia & Lithuania & France \\
Greece & Finland & Slovakia & Spain & Germany \\
Hungary & Latvia & Slovenia & & Italy \\
Ireland & Luxembourg & & & Poland \\
Malta & Netherlands & & & \\
Portugal & Romania & & & \\
United Kingdom & Sweden & & & \\
\hline
\end{tabular}

\section{National preferences for investment screening}

The weakness of the investment screening framework adopted by the EU comes mainly from its origins in the reconciliation of extremely diverse policy practices and preferences from the Member States. The EU Member States' decision on the EU-wide FDI screening mechanism provides a unique opportunity to study the determinants of national preferences for FDI screening. Unlike most existing research that focuses on one country (mainly the U.S., e.g. Kang, 1997; Graham \& Marchick, 2006), the case of the EU allows us to look at the national preferences for FDI screening a relatively diverse set of countries with distinctive socioeconomic characteristics.

When the European Commission decided to proceed with drafting an FDI screening policy in 2017, half of the EU Member States already had some national investment screening in place, while the other half did not-by choice or by oversight. Among the countries that already screen foreign investment, the nature of the procedures varies widely-for instance, ex ante vs. ex post, voluntary vs. mandatory, broad scope vs. specific sectors (Grieger, 2017). The push for an EU- wide ISM came primarily from France, Germany and, to some extent, Italy, with support from the European Commission. Most other Member States have expressed either indifference or strong opposition to the new policy.

To categorize EU countries' preferences for FDI screening, we interviewed 24 senior officials from the European Commission, the European Parliament, and national governments in Brussels in February 2019 and February 2020, in some Member States-including Bulgaria, Cyprus, Estonia, France, Greece, and Latvia-in 2018 and 2019, and online in January 2021. Each of the interviewees were asked to rate, based on their observation and on a five-point scale from oppose to support, each EU Member State's initial opinion on the EU-wide FDI screening mechanism back in late 2017 when the mechanism was first announced. Additional to the numeric ratings given to each EU Member State, we also asked the interviewees to explain the rationale behind each rating. All the policymakers in our sample 
independently came up with very similar ratings for each of the 28 Member States. ${ }^{10}$ We also cross-validated the ratings from this elite survey with press reports. Table 1 reports the ratings.

When France, supported by Germany and Italy, first raised the issue of the creation of a pan-European ISM at the June 2017 European Council summit, the other Member States reacted negatively and watered down the initial mandate for the Commission to examine scrutiny of foreign investments. France has a long history of concern and scrutiny over the political challenges raised by foreign investment, going back to worries about "Coca-Colonization" in the 1960s (Kuisel, 1993; Servan-Schreiber, 1968) and "Disneyification" in the 1980s (Kuisel, 2011). France reinforced its investment screening rules in 2004, after a wave of politically controversial bids, mostly from the U.S. It expanded the screening to new critical sectors, such as energy and telecommunications, in 2014 (Légifrance, 2014).

As the fourth destination for Chinese FDI in Europe in 2017, France tightened its national screening rules again in December 2018, this time in direct reaction to growing Chinese FDI, by expanding to more sectors, such as cybersecurity and artificial intelligence (Légifrance, 2018). During his visit in Beijing, the French finance minister, Bruno Le Maire, declared that "If investors come to France or Europe only to gain access to the best technology without benefiting France or any other European country then they are not welcome. There are looters in every country, and all of them need to understand that Europe has the means to protect itself" (Fouquet et al., 2018).

Germany, which was the top destination for Chinese FDI in Europe in 2017, grew concerned about Chinese investment in 2016 and became the driving force, along with France, behind the push towards a European screening framework (Chazan, 2018a). Until then, while Chinese FDI was growing fast in Mittelstand companies in the first half of the 2010 decade, Germany displayed no particular concerns. On the contrary, such investment was viewed quite positively, on the rationale that the Chinese and German economies were complementary and that Germany's open investment environment had belied its economic growth. Indeed, Chinese investors were often the only bidders and therefore the "saviors" when owners of family-run small and medium enterprises (SMEs) retired. Moreover, acquisitions by Chinese investors had proven to perform above-average in terms of job security. Both arguments were frequently made by representatives from both conservative and left-wing party members in Germany.

Germany's preferences on the desirability of investment screening, however, drastically changed in 2016 with the $€ 4.5$ billion acquisition of Kuka, a German company making advanced industrial robots, by Medea, a Chinese appliance company. The German government did not block the controversial transaction, which raised concern about the acquisition of technology to accelerate catching up and lack of reciprocal opportunities (Tsang, 2016). However, the German minister of

\footnotetext{
10 For each of the 28 Member States in 2017, Belgium's initial position was the only one that received different ratings among all our 24 interviewees, with one believing that Belgium was neutral, while the rest believing that it somewhat opposed the EU ISM. We use the modal value and code Belgium as "somewhat oppose".
} 
economic affairs, Sigmar Gabriel, expressed concerns regarding national security and tried to obtain assurances for the protection of Kuka's intellectual property. A few months later, concerns over the security challenges raised by Chinese investment were heightened by an even more controversial takeover bid, when the Chinese Fujian Grand Chip company tried to acquire Aixtron, a German chipmaker. The deal was blocked by the American authorities through the CFIUS process, since Aixtron operated a subsidiary in the U.S. This case demonstrated that the security-related impact of foreign acquisitions could extend beyond German and even EU borders, with the potential to affect relations with partners such as the U.S.

As a result of the shocks provoked by the back-to-back Kuka and Aixtron transactions, the German government and public became aware of Chinese investment in high-tech sectors, which until then had flown under the radar. These sectors were considered vital for Germany's "Industrie 4.0" vision, reigniting debates about whether China is a competitor or partner. Germany, therefore, tightened its investment screening procedures in 2017 by allowing the government to screen and block foreign investment in critical infrastructure for transactions involving a $25 \%$ foreign stake.

Other controversial transactions followed, leading Germany to push investment screening at the EU level. In 2017, the Chinese HNA Group took a 9.9\% share in Deutsche Bank, becoming the bank's largest shareholder. In February 2018 Chinese auto-maker Geely (owner of Volvo) made a US\$9 billion acquisition of $10 \%$ of Daimler, the parent company of Mercedes-Benz, becoming its largest shareholder. This transaction provoked particular concerns because the transfer of shares apparently "came out of nowhere" and because the main purpose of the acquisition seems to be Daimler's advanced battery technology for electric cars, the company's crown jewel (Chazan, 2018a). At the same time, Geely had a good reputation as an investor following the takeover of Volvo, and influential Christian Democratic Union (CDU) members from Baden-Württemberg (home to Daimler) were wary of EU or national legislation that would impede the intended investment in Daimler.

That year the German government barred China's energy grid from buying 20\% ownership of 50Hertz, an operator of high voltage electricity network in Germany, by directing state development bank KfW to take the $20 \%$ share in order to preempt the Chinese acquisition (Chazan, 2018b). In August 2018, after the German government threatened to intervene, Chinese company Yantai Taihai withdrew its bid for a German machine tool manufacturer in the aerospace and nuclear industry, Leifeld Metal Spinning (Chazan, 2018c). As a result, in December 2018, the German government lowered its threshold for screening (and potentially blocking) for national security concerns foreign takeovers from 25 to $10 \%$ shareholding in a German company. The Foreign Trade and Payments Act applies notably to defense and security companies, as well as those operating "critical infrastructure," such as power and telecoms. In January 2019, the main German business lobby, the Bundesverband der Deutschen Industrie, asked the German government for more effective protection against Chinese investments. The German government also announced that it was considering banning the Chinese telecom giant Huawei from the $5 \mathrm{G}$ network on national security grounds. "The way some in Germany see it, China is on a mission 
to suck the country dry of its technological know-how and engineering expertise, and supplant it as one of the world's leading industrial powers" (Chazan, 2018a).

As for the other 25 Member States, policymaker interviews, newspaper accounts, and anecdotal evidence suggest that their motivations for their initial rejection of or lukewarm support for the EU ISM varied considerably. We can roughly group these motivations as follows. One group of countries, such as Greece and Portugal, is said to have opposed screening because of their dependence on Chinese investment as a result of the euro crisis. Another group of countries initially opposed investment screening for ideological reasons, fearing that this was an anti-liberal, protectionist policy. These include Belgium, Estonia, Finland, Netherlands, and Sweden. Another set of countries seems to have initially opposed investment screening because their economies are dependent on being intermediaries of foreign investment: Cyprus, Ireland, Luxembourg, and Malta. These countries were particularly concerned that any screening mechanism would reduce their attractiveness to foreign investors, which could have grave consequences on their economies. Other countries were simply agnostic because they had not given much thought to the policy mechanism and themselves did not have a national screening mechanism, such as Bulgaria and Croatia.

Unlike the case of the United States (see Graham \& Marchick, 2006: chap. 4), policymakers at the EU level faced no corporate lobbying efforts due to its rapid, fragmented, and highly technocratic decision-making process. When the negotiation process was initiated in November 2017, Estonia, then assuming the presidency of the Council of the European Union, decided to delegate the discussion of Commission proposal and the formulation of the Council position on the EU FDI screening mechanism mainly to the Working Party on Trade Question, with inputs from two other working parties on external and internal trade policy which dealt with the legal implications of the EU FDI screening mechanism vis-à-vis existing multilateral and bilateral trade and investment treaties, and Member States' national laws respectively. This move was not without controversy. On the one hand, the discussions were fragmented across, and highly technical and lengthy within, these working parties. ${ }^{11}$ On the other hand, the European Commission was under substantial time pressure on FDI screening regulations as its term was approaching an end in $2019 .{ }^{12}$

\section{Determinants of national preferences for FDI screening}

To complement our qualitative evidence, we conduct a quantitative analysis of the potential determinants of the initial positions of the Member States on the European screening mechanism. The qualitative evidence presented in Sect. 4 suggests that (1) EU Member States with higher levels of technology supported the EU FDI screening mechanism due to their concern over unreciprocated technological

\footnotetext{
11 Interviews with senior policymakers from national delegations to the EU and the European Commission who were involved in the FDI screening mechanism negotiation process, Brussels, February 2020.

12 Interview with a senior officer in the European Commission Directorate General for Trade. Online, January 2021.
} 
transfer to foreign countries-especially adversarial ones - through FDI, while (2) Member States that relied heavily on FDI from China were against the screening mechanism because they were afraid of losing control over who gets to invest in the country to the European Commission. These two findings allow us to generate two testable hypotheses on the determinants of Member States' initial positions on the EU screening mechanism:

- Hypothesis 1 (H1): Member States with a more technologically intense national economy tend to support the supranational FDI screening mechanism.

- Hypothesis 2 (H2): Member States that rely more heavily on Chinese FDI tend to oppose the supranational FDI screening mechanism.

\subsection{Method}

Neither the technological level nor the reliance on Chinese FDI of an EU Member State is exogenous. In a large- $N$ setting, we would make use of control variables to bolster the plausibility of the conditional independence assumption. However, the EU had only 28 Member States (now 27) when the EU-wide ISM was proposed and so we have only 28 observations. At the same time, there are myriads of factors that influence Member States' technological levels and the reliance on Chinese FDI. The need to control for a large set of variables is unfeasible in a conventional linear regression setting with only 28 observations because there are far more covariates than observations. We overcome some of these challenges by leveraging recent advances in the machine learning and causal inferences literature. Although the small sample size remains an issue in the Double Machine Learning framework we describe below-in particular, the lack of common support with only 28 observations can be problematic, we can be more confident about our results if this quantitative exercise corroborates with our findings from process tracing.

We use the Double Machine Learning (DML) framework proposed by Chernozhukov et al. $(2017,2018)$ to test our two hypotheses. ${ }^{13}$ Under the DML framework, in the first stage of the analysis, we debias the main independent variables (IVs) of interest, namely technological intensity and reliance on Chinese FDI, by predicting these main IVs using the control variables, including current and lagged research and development (R\&D) expenditure, persons with tertiary education, GDP, and FDI stocks (Table 2). In the second stage, we calculate the association between the debiased IVs and support for the EU FDI screening mechanism to estimate the effects of the IVs on the outcome. The DML framework is flexible and works with a wide variety of machine learning models. In both stages, we use a random forest, regression tree, and boosted tree to model

\footnotetext{
13 See Online Appendix A available on the Review of International Organizations' webpage for further technical details.
} 
Table 2 First-Stage Model Specifications

\begin{tabular}{|c|c|c|c|}
\hline $\begin{array}{l}\text { Independent } \\
\text { Variable of } \\
\text { Interest }\end{array}$ & Measure & $\begin{array}{l}\text { Year of } \\
\text { Measure }\end{array}$ & Control Variables ${ }^{*}$ \\
\hline $\begin{array}{l}\text { Technological } \\
\text { Intensity }\end{array}$ & $\begin{array}{l}\log (\text { high-tech value added } \\
\text { in million USD) } \\
\log (\text { high-tech production in } \\
\text { million USD) } \\
\log (\text { high-tech exports in } \\
\text { USD) }\end{array}$ & 2015 & $\begin{array}{l}\text { For measures taken in 2015: } \\
\text { - R\&D expenditure (\% GDP, current year to } \\
\text { lagged } 3 \text { years) } \\
\text { - Persons with tertiary education and/or } \\
\text { employed in science and technology (\% } \\
\text { adult population, current year to lagged } 3 \\
\text { years) } \\
\text { - log(GDP in million USD) } \\
\text { - GDP growth rate (\%) } \\
\text { - log(FDI Stock in million EUR) } \\
\text { - World Bank's Ease of Doing Business } \\
\text { Index } \\
\text { - World Governance Indicators (Control } \\
\text { of corruption, Governance effectiveness, } \\
\text { Regulatory quality, Rule of law) } \\
\text { - R\&D expenditure (\% GDP, current year to } \\
\text { lagged } 5 \text { years) } \\
\text { - Persons with tertiary education and/or } \\
\text { employed in science and technology (\% } \\
\text { adult population, current year to lagged } 5 \\
\text { years) } \\
\text { •Existing national FDI screening mecha- } \\
\text { nism in current year }\end{array}$ \\
\hline $\begin{array}{l}\text { Reliance on } \\
\text { Chinese FDI }\end{array}$ & $\begin{array}{l}\text { Net FDI flow from China } \\
\text { (billion USD) } \\
\text { Net accumulated FDI Flow } \\
\text { from China (billion USD) } \\
\text { Net FDI flow from China } \\
\text { (ratio to total FDI flow) } \\
\text { Net accumulated FDI Flow } \\
\text { (ratio to total FDI stock) }\end{array}$ & 2017 & $\begin{array}{l}\text { For measures taken in 2017: } \\
\text { - } \log (\mathrm{GDP} \text { in million USD, current to lagged } \\
2 \text { years) } \\
\text { - GDP growth rate (\%, current to lagged } 2 \\
\text { years) } \\
\text { - } \log \text { (FDI Stock in million EUR, current to } \\
\text { lagged } 2 \text { years) } \\
\text { - World Bank's Ease of Doing Business } \\
\text { Index } \\
\text { - World Governance Indicators (Control } \\
\text { of corruption, Governance effectiveness, } \\
\text { Regulatory quality, Rule of law) } \\
\text {-Existing national FDI screening mechanism } \\
\text { in current year }\end{array}$ \\
\hline
\end{tabular}

${ }^{*}$ Current year refers to the year of measure for the independent variable of interest, and the lagged variables are relative to the current year

each specification in Table 2 with seven-fold cross validation and 5,000 iterations. ${ }^{14}$ We use these three tree-based models because they can handle binary, categorical, and

14 The sample splitting resulted from cross-validation allows for point estimators that are approximately unbiased and normally distributed even in an extremely high dimensional setting. These characteristics of the DML point estimators also allow us to construct valid confidence intervals (Chernozhukov et al., 2018). We use seven folds because the number of EU Member States in 2017, 28, is divisible by seven. Online Appendix C provides results using four folds. 
continuous variables in a high-dimensional setting with more covariates than observations. These models are also robust to outliers and non-linearity (see James et al., 2015: chap. 8). Following Chernozhukov et al. (2018: C39), we create an additional hybrid model for each specification, which we call the "best" model, using these steps: In the first stage, we select the model with the lowest out-of-bag (OOB) prediction mean squared error (MSE). In the second stage, we use the debiased main IV from this selected model to estimate the effects on support for the FDI screening mechanism using all the three models, and then select the one with the lowest OOB MSE. ${ }^{15}$

\subsection{Data}

Our outcome variable is a Member State's initial position on the EU-wide screening mechanism, measured using the five-point scale from oppose (-2) to neutral (0) and support (2) presented in Sect. 4. To test for H1, we measure a country's technological levels using value added and production (gross output) by industries that are classified as high or medium-high R\&D intensity in International Standard Industrial Classification (ISIC), Revision 4 (see Galindo-Rueda \& Verger, 2016). ${ }^{16}$ The value-added and production data come from the Trade in Value Added (TiVA) data set published by OECD Stat (2018). Since the latest available TiVA data dates back to only 2015, two years before our outcome variable is measured, we supplement the analysis with high-tech exports data from 2017 published by the World Bank (2019). Figure 2 plots the correlations between these measures of technological intensity and support for the EU screening mechanism.

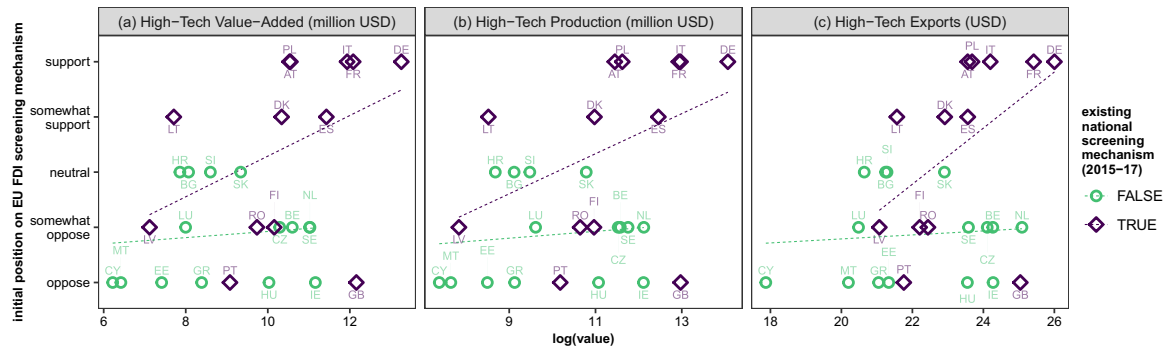

Fig. 2 Correlations between Technological Intensity and Support for EU-wide FDI Screening Mechanism. Each panel represents different measures of technological intensity. Dotted lines represent the linear best fit lines

\footnotetext{
${ }^{15}$ For example, if a random forest provides the lowest OOB MSE in the first stage, we use the debiased IV from the random forest in all three models in the second stage. If boosting provides the lowest OOB MSE in the second stage, the best model would be a combination of random forest and boosting. On the other hand, if random forest provides the lowest OOB MSE in the second stage, the best model would be the same as a model using random forest in both stages.

${ }^{16}$ These industries are chemicals and pharmaceutical products, computers, electronic and electrical equipment, machinery and equipment, transport equipment, and IT and other information services.
} 
To test $\boldsymbol{H 2}$, we utilize four different measures of reliance on inward FDI from China, namely net FDI flow from China (in billion USD), net accumulated FDI flow from China (in billion USD), net FDI flow from China as a ratio of total net inward FDI flow, and net accumulated FDI flow from China as a ratio of total net accumulated inward FDI flow. The raw data on FDI flow from China, total annual FDI flow, and total annual FDI stock for each Member State are from EuroStat (2019). The accumulated FDI flow from China is reported by the Chinese Ministry of Commerce (MOFCOM) as part of its annual outward investment data and available through the CEIC database. ${ }^{17}$ These four measures can take negative values if the host EU country has more FDI in China than China has in the host EU country. Since these four measures are all highly right-skewed and may be negative, we transform them by taking the cubic root (see Cox, 1992) (Fig. 3).

Our control variables include a variety of factors that directly improve a country's higher technological intensity, such as R\&D expenditure and persons with tertiary

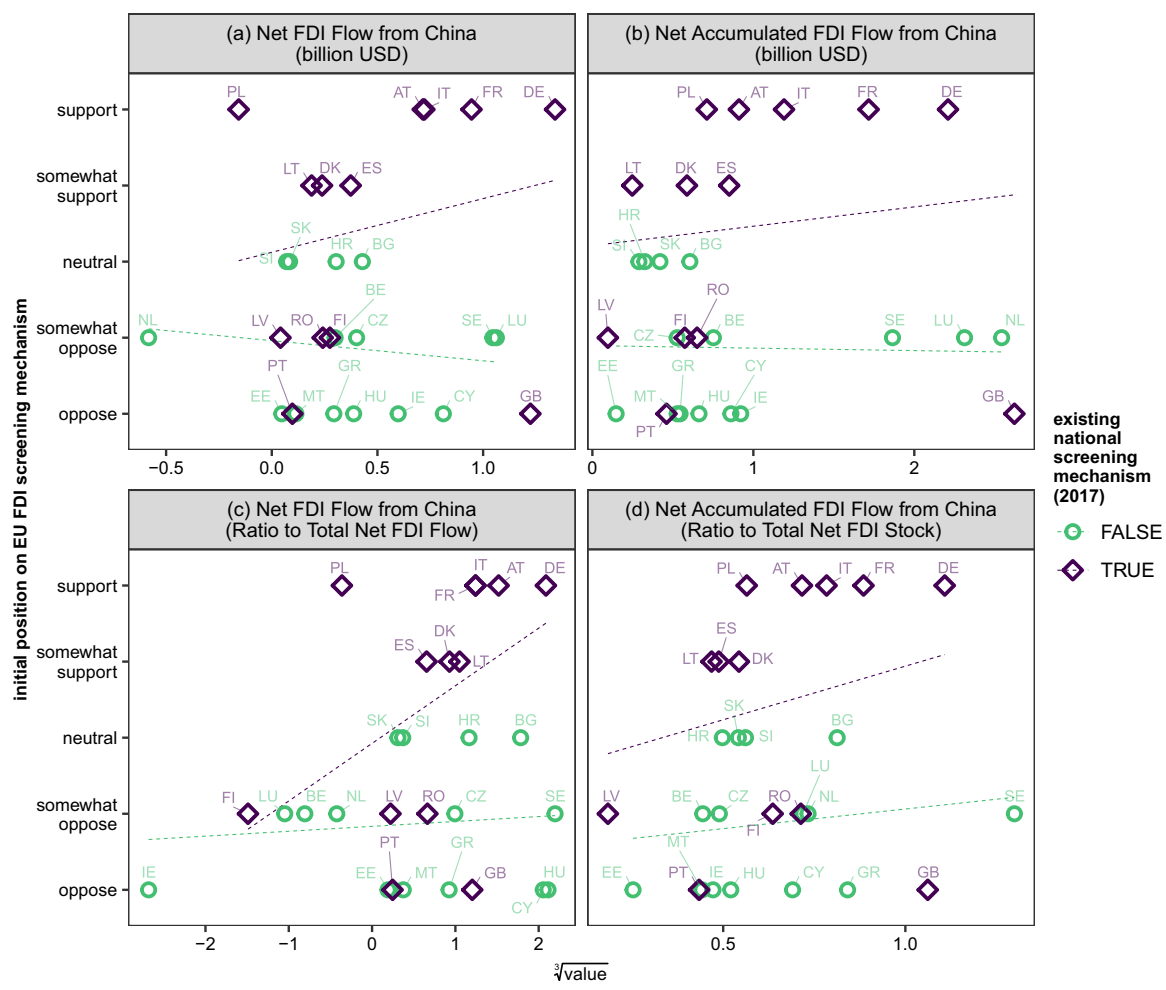

Fig. 3 Correlations between Reliance on Chinese FDI and Support for EU-wide FDI Screening Mechanism. Each panel represents different measures of reliance on Chinese FDI. Dotted lines represent the linear best fit lines

\footnotetext{
${ }^{17}$ Most EU Member States report their total FDI position through EuroStat, but some Member States have data missing for the year 2017. Given the small sample size in this analysis, such missing data is detrimental to inferences. As such, we used the accumulated FDI reported by MOFCOM.
} 
education and/or employed in science and technology. We also include factors that are conducive to high-tech production, including the World Bank's Ease of Doing Business Index and World Governance Indicators. To capture the size and other characteristics of the economy, we also control for GDP, GDP growth, FDI stocks, and whether a national screening mechanism existed in 2017. Table 2 presents the full specification of the first-stage models. Unless otherwise specified, the data is from EuroStat's online database. ${ }^{18}$

\subsection{Results}

Figure 4 reports the estimated effects of technological intensity and reliance on Chinese FDI on Member States' initial support for the EU-wide FDI screening mechanism from the best model described in Sect. 5.1. ${ }^{19}$ Consistent with $\boldsymbol{H 1}$, all our measures of technological intensity are positively and statistically significantly correlated with countries' initial support for the EU FDI screening mechanism. Each percentage increase in high-tech value added, production, and exports is respectively associated with 0.6955 -point (standard error $(\mathrm{SE})=0.3258,95 \%$ confidence interval $(\mathrm{CI})=[0.0569,1.3341]), 0.8207$-point $(\mathrm{SE}=0.3019,95 \% \mathrm{CI}=[0.2289,1.4124])$,

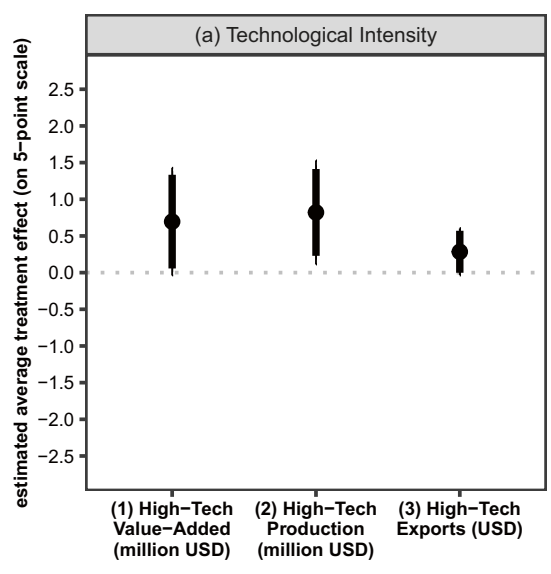

$\log ($ value)

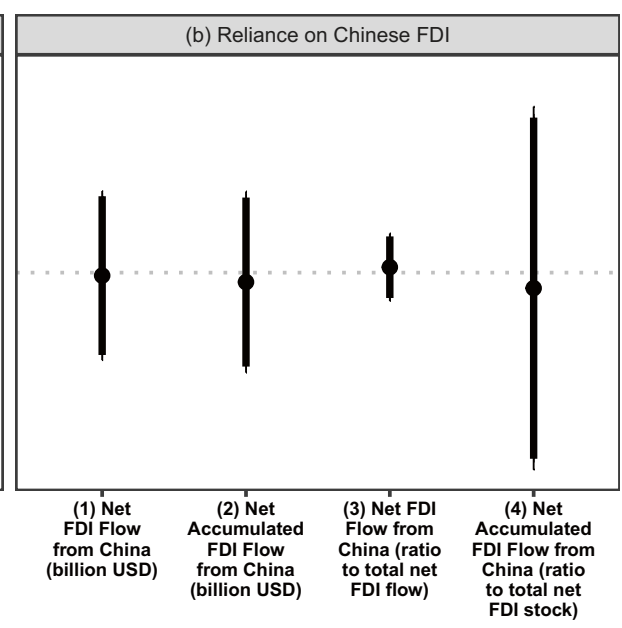

$\sqrt[3]{\text { value }}$

Fig. 4 Estimated Average Effects on Member States' Initial Support for the EU-wide FDI Screening Mechanism. Point estimates and standard errors are based on orthogonal estimating equations with seven-fold cross-validation. Results are based on 5,000 splits with point estimates calculated using the median method. Each panel consists of different measures for each of the two main independent variables of interest. The thick error bars represent the $95 \%$ confidence intervals (CIs) based on standard errors (SEs) from the median method, the thin error bars represent the 95\% CIs calculated using the SEs adjusted for variability across splits using the median method (see Online Appendix A)

\footnotetext{
18 See Online Appendix B for summary statistics.

19 Online Appendix C compares the results from other tree-based and ordinary least squares (OLS) models, which are mostly similar.
} 
and 0.2842-point $(\mathrm{SE}=0.1461,95 \% \mathrm{CI}=[-0.0021,0.5705])$ increase (on a 5-point scale) in support for the screening mechanism.

On the other hand, we find no evidence in support of $\boldsymbol{H} 2$. None of the four measures of reliance on Chinese FDI has statistically significant relationship with each Member State's initial support for the EU-wide FDI screening mechanism. The estimated effects are all close to zero: -0.0407 -point $(\mathrm{SE}=0.5521,95 \% \mathrm{CI}=-1.1228$, $1.0415]),-0.1290$-point $(\mathrm{SE}=0.5879,95 \% \mathrm{CI}=-1.2812,1.0233]), 0.0738$-point $(\mathrm{SE}=0.2142,95 \% \mathrm{CI}=-0.3461,0.4937)$, and -0.2123 -point $(\mathrm{SE}=1.1866,95 \%$ $\mathrm{CI}=-2.5379,2.1134]$ for, respectively, net FDI flow in 2017 and net accumulated FDI flow from China, both in absolute terms and as a ratio to total net FDI flow or stock.

\section{Discussion}

Our results suggest that, consistent with $\mathbf{H 1}$, Member States with higher technological levels were more supportive of the EU-wide screening mechanism. As we have highlighted in Sect. 4, the earliest major proponents of the pan-EU screening mechanism were France, Germany, and Italy, all of which already had their national FDI screening mechanism in place when the EU-wide screening mechanism was proposed in 2017. These Member States also happen to have had some of the highest levels of technology (measured in national high-technology exports in USD, see Fig. 5). These Member States' own experience in protecting their high-technology

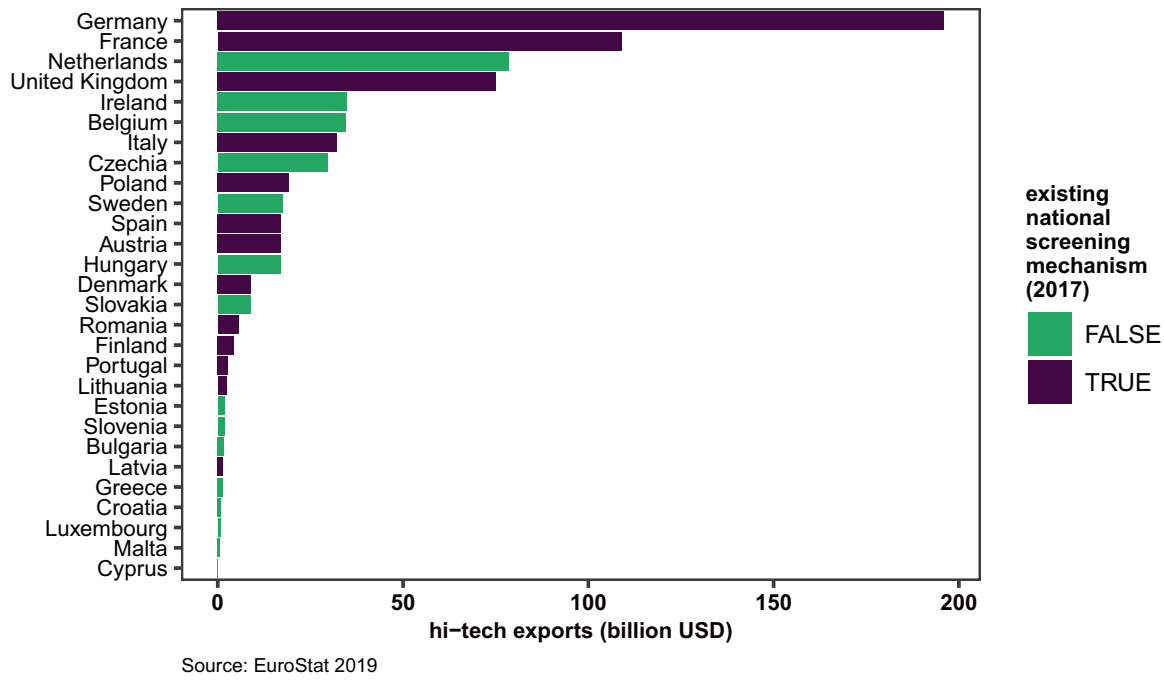

Fig. 5 Volume of High-Technology Exports by EU Member States, 2017 
sectors and in controlling technological transfer overseas motivated their EU-level FDI-screening proposal. ${ }^{20}$

The null results from the tests for $\boldsymbol{H} 2$ may have been a result of two countervailing effects of Chinese inwards FDI. On the one hand, reliance on Chinese FDI can raise the salience of and skepticism towards the intentions of Chinese investors, especially when they invest in strategic industries that are related to national security. This form of reliance on Chinese FDI can lead to Member States' support for the screening mechanism. On the other hand, if a Member State already relies heavily on Chinese FDI, the Member State might be opposed to the screening mechanism over concerns that it would lose its sovereignty and future Chinese investment into the country will be blocked at the EU level. The combined effects of these two sets of opposite effects might be the reason for the null results in our analyses.

It is important to note that Chinese FDI in different industries or sectors can prompt different types of response from Member States regarding the EU-wide FDI screening mechanism. For instance, Bulgaria receives substantial FDI from China and Russia in seaside real estate. The strategic or national security-related value of real estate is hardly comparable to that of the aerospace industry. ${ }^{21}$ Similarly, Chinese and Russian investment in Cyprus is mostly in real estate. Ideally, we can quantitatively disaggregate these two countervailing effects using country-year-industrylevel data to account for the heterogeneity across sectors. While such fine-grained data is not available to us at the moment, future research could use the sectoral breakdown of Chinese FDI to examine heterogeneous effects.

\section{Conclusion}

This paper explained the major motivations behind EU countries' support for restricting FDI openness through the institutionalization of a pan-European ISM. While each Member State had its unique set of reasons to support or oppose FDI screening initially, both our qualitative and quantitative evidence show that the technological level of the country is the most important determinant of national preferences for FDI screening. Countries with higher technological levels are more concerned about unreciprocated international transfer of technologies, especially that of strategic ones. Although the evidence for the effects of Chinese FDI on national preferences for FDI screening is mixed, it is an area of growing importance that warrants further attention in future research.

We have only examined the initial reactions of the Member States to the proposed creation of an EU-wide ISM. The policy process happened quite fast, with only fourteen months from the launch of the policy planning by the Commission in September 2017 until the adoption of the Regulation in November 2018. We argued that in exchange for this speed, the framework adopted was quite barebones, the

\footnotetext{
${ }^{20}$ Interview with a senior trade policy official of the Bulgarian Delegation to the EU. Brussels, February 2020.

${ }^{21}$ Interview with a senior trade policy official of the Bulgarian Delegation to the EU. Brussels, February 2020.
} 
lowest common denominator of initially very diverse national positions. As so often throughout the history of European integration, this new policy represents the lowest common denominator of the diverse Member State preferences and may be revisited towards more integration, either functionally or politically, at a later date. We suggest that the framework might be strengthened in the future through a "failing forward" dynamic (Jones et al., 2016): because the original framework adopted by the Member States is so empty, yet it forces some sharing and cooperation, it may contain the seeds of a future crisis-for instance if a Chinese acquisition in a Member State proceeds despite worries, warnings, and outrage by other Member States, then one can expect further integration of FDI screening to happen. This regulation is only a first step.

Indeed, ISMs in Europe have multiplied and tightened drastically throughout 2020 as a result of the COVID-19 pandemic (Bauerle Danzman \& Meunier, 2021). Barriers to FDI have proliferated worldwide, with at least 42 new barriers to entrymainly in the form of FDI screening and the suspension of foreign work visas-put in place between April and July 2020 (Nimac, 2020). In the EU, many companies hit hard by the pandemic-induced economic crisis have become ripe for foreign takeovers, particularly in the healthcare and pharmaceutical industries. This has led the Commission to warn about the dangers of unscreened investment to national security and to recommend a rapid transition to robust national investment screening: Member States which "currently do not have a screening mechanism, or whose screening mechanisms do not cover all relevant transactions, [should] set up a fullfledged screening mechanism and in the meantime [should] use all other available options to address cases where the acquisition or control of a particular business, infrastructure or technology would create a risk to security or public order in the EU, including a risk to critical health infrastructures and supply of critical inputs" (European Commission, 2020c: 2). As a result, several Member States have now created new screening mechanisms (e.g. Ireland and Spain), while others have made investment review more restrictive by broadening sectors covered (e.g. France) and lowering thresholds for review (e.g. Germany). In June 2020, the European Commission also proposed for the first time to tackle the issue of the distortive effects caused by foreign subsidies in the Single Market, especially in facilitating the acquisition of EU companies (European Commission, 2020a).

These recent developments towards the convergence of European ISMs are consistent with the EU's new trade strategy released in February 2021, which vows to promote "open strategic autonomy", notably by "increasing the EU's capacity to pursue its interests and enforce its rights" (European Commission, 2021). The EU has long stood as a model for openness towards capital flows and FDI. Whether the emergence of investment screening mechanisms leads to a renewed sense of Member State confidence in investment among Member States, and return to FDI growth following the recession, or a nationalist chilling effect and protectionism amid the global downturn, remains an open question.

Supplementary information The online version contains supplementary material available at https://doi. org/10.1007/s11558-021-09436-y. 
Acknowledgements We thank participants of the panel on "FDI: Determinants and Effects" at the conference of the International Studies Association, Toronto, March 27-30, 2019 and at the Conference on the International Research Conference on Global Economic Relations in the Trump Era and After in Ottawa on January 31, 2020. We also thank Simon Evenett, Noel Foster, Haosen Ge, Lars Nilsson, Helen Milner, and three anonymous reviewers for their helpful comments and suggestions at different stages of this project. All errors remain our own. We are very grateful to the many anonymous EU and Member States officials who accepted to be interviewed for this project in August 2018, February and November 2019, February 2020, and January 2021.

Funding This project was funded by the Princeton-Sciences Po EUROGLOB and Princeton-University of Geneva EUROCOMPLEX partnerships.

\section{References}

Alfaro, L., Chanda, A., Kalemli-Ozcan, S., \& Sayek, S. (2010). Does Foreign Direct Investment Promote Growth? Exploring the Role of Financial Markets on Linkages. Journal of Development Economics, 91(2), 242-256.

Anwar, S. T. (2012). FDI Regimes, Investment Screening Process, and Institutional Frameworks: China versus Others in Global Business. Journal of World Trade, 46(2), 213-248.

Baker McKenzie (2019). Chinese FDI into North America and Europe in 2018 Falls $73 \%$ to six-year low of $\$ 30$ billion. Press release. London: Baker McKenzie, January 14. https://www.bakermckenzie.com/en/ newsroom/2019/01/chinese-fdi.

Basedow, J. R. (2017). The EU in the Global Investment Regime: Commission Entrepreneurship, Incremental Institutional Change and Business Lethargy. Routledge.

Basu, P., Chakraborty, C., \& Reagle, D. (2003). Liberalization, FDI, and Growth in Developing Countries: A Panel Cointegration Approach. Economic Inquiry, 41(3), 510-516.

Basu, P., \& Guariglia, A. (2007). Foreign Direct Investment, Inequality, and Growth. Journal of Macroeconomics, 29(4), 824-839.

Bauerle Danzman, S. (2019). Merging interests: when domestic firms shape FDI policy. Cambridge University Press.

Bauerle Danzman, S. (2020). Foreign direct investment policy, domestic firms, and financial constraints. Business and Politics, 22(2), 279-306.

Bauerle Danzman, S. (2021). Investment screening in the shadow of weaponized interdependence. In D. W. Drezner, H. Farrell, \& A. L. Newman (Eds.), The uses and abuses of weaponized interdependence (pp. 257-272). Brookings Institution Press.

Bauerle Danzman, S., \& Meunier, S. (2021). The big screen: global crises and the diffusion of foreign investment review. Paper presented at the COVID-19 and post-pandemic investment and development conference. Bloomington, IN, March 11.

Bitzer, J., \& Kerekes, M. (2008). Does Foreign Direct Investment Transfer Technology across Borders? New Evidence. Economics Letters, 100(3), 355-358.

Blanchard, J. M. F., \& Zeng, K. (2019). "Chinese Outward Foreign Direct Investment (COFDI): A Primer and Assessment of the State of COFDI Research." In Handbook on the International Political Economy of China, 76-97. Northampton, MA: Edward Elgar.

Blomström, M., Lipsey, R. E., \& Zejan, M. (1994). What Explains the Growth of Developing Countries? In W. J. Baumol, R. R. Nelson, \& E. N. Wolff (Eds.), Convergence of Productivity: Cross-National Studies and Historical Evidence (pp. 243-259). Oxford University Press.

Borensztein, E., De Gregorio, J., \& Lee, J. -W. (1998). How Does Foreign Direct Investment Affect Economic Growth? Journal of International Economics, 45(1), 115-135.

Buch, C. M., \& Lipponer, A. (2010). Volatile Multinationals? Evidence from the Labor Demand of German Firms. Labour Economics, 17(2), 345-353.

Bungenberg, M., Griebel, J., \& Hindelang, S. (Eds.). (2011). International Investment Law and EU Law. Springer, Berlin Heidelberg.

Canes-Wrone, B., Mattioli, L., \& Meunier, S. (2020). Foreign Direct Investment Screening and Congressional Backlash Politics in the United States. British Journal of Politics and International Relations, 22(4), 666-678 
Chaisse, J. (Ed.). (2019). China's International Investment Strategy: Bilateral, Regional, and Global Law and Policy. Oxford University Press.

Chazan, G. (2018a). "Backlash Grows over Chinese Deals for Germany’s Corporate Jewels." Financial Times, March 13. https://www.ft.com/content/391637d2-215a-11e8-a895-1ba1f72c2c11

Chazan, G. (2018b). "Germany Acts to Protect Energy Group from Chinese.” Financial Times, July 27. https://www.ft.com/content/a39c799c-91ab-11e8-b639-7680cedcc421

Chazan, G. (2018c). "Germany Plans Further Foreign Investment Curbs.” Financial Times, August 7. https://www.ft.com/content/6ff764e8-9a1c-11e8-ab77-f854c65a4465

Chernozhukov, V., Chetverikov, D., Demirer, M., Duflo, E., Hansen, C., \& Newey, W. (2017). Double / Debiased / Neyman Machine Learning of Treatment Effects. American Economic Review, 107(5), 261-265.

Chernozhukov, V., Chetverikov, D., Demirer, M., Duflo, E., Hansen, C., Newey, W., \& Robins, J. (2018). Double/Debiased Machine Learning for Treatment and Structural Parameters. Econometrics Journal, 21(1), C1-C68.

Chilton, A. S., Milner, H. V., \& Tingley, D. (2020). Reciprocity and Public Opposition to Foreign Direct Investment. British Journal of Political Science, 50(1), 129-153.

Cox, N. J. (1992). Precipitation statistics for geomorphologists: Variations on a theme by Frank Ahnert. Catena Supplement, 23:189-212.

De Gucht, K. (2012). EU-China Investment: A Partnership of Equals. Speech. Brussels: European Commission, June 7. https://ec.europa.eu/commission/presscorner/detail/en/SPEECH_12_421

De Sarnez, M. (2012). On EU and China: Unbalanced Trade? Report 2010/2301(INI). Brussels: European Parliament, April 20. https://www.europarl.europa.eu/doceo/document/A-7-2012-0141_EN. html

Dür, A., Eckhardt, J., \& Poletti, A. (2020). Global Value Chains, the Anti-Globalization Backlash, and EU Trade Policy: A Research Agenda. Journal of European Public Policy, 27(6), 944-956.

European Commission. (2011). Cabinet Newsletter. Newsletter 33. Brussels: European Commission, February 11. https://ec.europa.eu/archives/commission_2010-2014/tajani/about/newsletter/files/ 2011-02/cabnews-33-20110211_en

European Commission. (2017). Harnessing Globalisation. Reflection paper COM(2017) 240. Brussels: European Commission, May 10. https://ec.europa.eu/info/publications/reflection-paper-harnessingglobalisation_en

European Commission. (2020a). "Commission Adopts White Paper on Foreign Subsidies.” Press release. Brussels: European Commission, June 17. https://ec.europa.eu/commission/presscorner/detail/en/ip_ 20_1070

European Commission. (2020b). "Frequently Asked Questions on Regulation (EU) 2019/452 Establishing a Framework for the Screening of Foreign Direct Investments into the Union.” Memo. Brussels: European Commission, October 9. https://trade.ec.europa.eu/doclib/docs/2019/june/tradoc_157945. pdf

European Commission. (2020c). Guidance to the Member States Concerning Foreign Direct Investment and Free Movement of Capital from Third Countries, and the Protection of Europe's Strategic Assets, Ahead of the Application of Regulation (EU) 2019/452 (FDI Screening Regulation). Communication from the Commission C(2020) 1981 final. Brussels: European Commission, March 25. https://trade.ec. europa.eu/doclib/docs/2020/march/tradoc_158676.pdf

European Commission. (2021). Trade Policy Review: An Open, Sustainable and Assertive Trade Policy. Communication from the Commission COM(2021) 66 final. Brussels: European Commission, February 18. https://investmentpolicy.unctad.org/publications/1213/investment-policy-monitor-specialissue---national-security-related-screening-mechanisms-for-foreign-investment-an-analysis-ofrecent-policy-developments

European Parliament and Council of the European Union. (2019). Regulation (EU) 2019/452 of the European parliament and of the council of 19 March 2019 establishing a framework for the screening of foreign direct investments into the union. Official Journal of the European Union, no. LI 79: 1-14. http://data.europa.eu/eli/reg/2019/452/oj.

European Union. (2007). Treaty of Lisbon Amending the Treaty on European Union and the Treaty Establishing the European Community. Treaty full-text. Brussels: European Union, December13. https:// eur-lex.europa.eu/legal-content/EN/TXT/?uri=celex\%3A12007L\%2FTXT

EuroStat. (2019). Balance of Payments -International Transactions (BPM6). Dataset. Brussels: European Commission, June 17. https://ec.europa.eu/eurostat/web/balance-of-payments/data/database 
Figini, P., \& Görg, H. (1999). Multinational Companies and Wage Inequality in the Host Country: The Case of Ireland. Weltwirtschaftliches Archiv, 135(4), 594-612.

Figini, P., \& Görg, H. (2011). Does Foreign Direct Investment Affect Wage Inequality? An Empirical Investigation. The World Economy, 34(9), 1455-1475.

Fouquet, H., Deen M., \& De Beaupuy, F. (2018). France tightens controls on Chinese investment to protecttech. Bloomberg, January 9. https:/www.bloomberg.com/news/articles/2018-01-09/france-resistschinese-investment-to-shield-tech-from-predators

Frye, T., \& Pinto, P. M. (2009). The Politics of Chinese Investment in the US. In K. P. Sauvant (Ed.), Investing in the United States: Is the US Ready for FDI from China? (pp. 85-121). Edward Elgar.

Galindo-Rueda, F., \& Verger, F. (2016). "OECD Taxonomy of Economic Activities Based on R\&D Intensity." OECD Science, Technology and Industry Working Papers (July 16).

Graham, E. M., \& Marchick, D. M. (2006). US National Security and Foreign Direct Investment. Peterson Institute for International Economics.

Grieger, G. (2017). Foreign Direct Investment Screening: A Debate in Light of China-EU FDI Flows. Briefing PE 603.941. Brussels: European Parliamentary Research Service. https://www.europarl. europa.eu/RegData/etudes/BRIE/2017/603941/EPRS_BRI(2017)603941_EN.pdf

Herzer, D., Hühne, P., \& Nunnenkamp, P. (2014). FDI and Income Inequality-Evidence from Latin American Economies. Review of Development Economics, 18(4), 778-793.

Jackson, J. K. (2020). The Committee on Foreign Investment in the United States (CFIUS). Report RL33388. Washington, DC: Congressional Research Service, February 14. https://fas.org/sgp/crs/ natsec/RL33388.pdf

James, G., Witten, D., Hastie, T., \& Tibshirani, R. (2015). An Introduction to Statistical Learning with Applications in R. Springer.

Jones, E., Daniel Kelemen, R., \& Meunier, S. (2016). Failing Forward? The Euro Crisis and the Incomplete Nature of European Integration. Comparative Political Studies, 49(7), 1010-1034.

Jones, L., \& Zeng, J. (2019). Understanding China's 'Belt and Road Initiative': Beyond 'Grand Strategy' to a State Transformation Analysis. Third World Quarterly, 40(8), 1415-1439.

Juncker, J.-C. (2017). State of the union address 2017. Speech. Brussels: European Commission, September 13. https://ec.europa.eu/commission/presscorner/detail/en/SPEECH_17_3165.

Kang, C. S. E. (1997). U.S. Politics and Greater Regulation of Inward Foreign Direct Investment. International Organization, 51(2), 301-333.

Knell, M., \& Radošević, S. (2000). FDI, Technology Transfer and Growth in Economic Theory. In G. Hunya (Ed.), Integration Through Foreign Direct Investment: Making Central European Industries Competitive (pp. 28-34). Edward Elgar.

Kobrin, S. J. (2005). The Determinants of Liberalization of FDI Policy in Developing Countries: A Cross-Sectional Analysis, 1992-2001. Transnational Corporations, 14(1), 67-104.

Kuisel, R. F. (1993). Seducing the French: The Dilemma of Americanization. University of California Press.

Kuisel, R. F. (2011). The French Way: How France Embraced and Rejected American Values and Power. Princeton University Press.

Lang, A. (2019). Heterodox Markets and 'Market Distortions' in the Global Trading System. Journal of International Economic Law, 22(4), 677-719.

Le Corre, P., \& Sepulchre, A. (2016). China Abroad: The Long March to Europe. Report. Washington, DC: Brookings Institution, June 27. https://www.brookings.edu/research/china-abroad-the-longmarch-to-europe/

Le Guernigou, Y., \& Thomas, L. (2017). "France, Germany, Italy Urge Rethink of Foreign Investment in EU.” Reuters, February 14. https://www.reuters.com/article/uk-eu-trade-france-idUKKBN15T1ND

Leblond, P., \& Viju-Miljusevic, C. (2019). EU Trade Policy in the Twenty-First Century: Change, Continuity and Challenges. Journal of European Public Policy, 26(12), 1836-1846.

Légifrance. (2014). Décret n²014-479 du 14 mai 2014 Relatif aux Investissements Étrangers soumis à Autorisation Préalable [Decree $\mathrm{n}^{\circ} 2014-479$ dated May 14, 2014 related to foreign investments subject to prior authorization (in French)]. Decree 2014-479. May 14. https://www.legifrance.gouv.fr/ loda/id/JORFTEXT000028933611/

Lenihan, A. T. (2018). Balancing Power without Weapons: State Intervention into Cross-Border Mergers and Acquisitions. Cambridge University Press. 
Malmström, C. (2015). “Answer to Question No. E-009974/14.” Parliamentary questions. Brussels: European Parliament, January 29. https://www.europarl.europa.eu/doceo/document/E-8-2014-009974ASW_EN.html

Meunier, S. (2014). Divide and Conquer? China and the Cacophony of Foreign Investment Rules in the EU. Journal of European Public Policy, 21(7), 996-1016.

Meunier, S. (2017). Integration by stealth: how the European Union gained competence over foreign direct investment. JCMS: Journal of Common Market Studies, 55(3), 593-610.

Meunier, S. (2019). Beware of Chinese bearing gifts: why China's direct investment poses political problems in Europe and the United States. In J. Chaisse (Ed.), China's investment three-prong strategy: bilateral, regional, and global tracks (pp. 345-359). Oxford University Press.

Meunier, S., \& Czesana, R. (2019). From Back Rooms to the Street? A Research Agenda for Explaining Variation in the Public Salience of Trade Policy-Making in Europe. Journal of European Public Policy, 26(12), 1847-1865.

Meunier, S., \& Nicolaidis, K. (2019). The geopoliticization of European trade and investment policy. JCMS: Journal of Common Market Studies, 57(S1), 103-113.

Nimac, I. A. (2020). "COVID-19 and FDI: How Should Governments Respond?" Columbia FDI Perspectives, no. 288: 1-3. http://ccsi.columbia.edu/files/2020/10/No-288-Nimac-FINAL.pdf

OECD Directorate for Financial and Enterprise Affairs. (2020). FDI Regulatory Restrictiveness Index. Paris: Organisation for Economic Co-operation and Development. https:/www.oecd.org/investment/ fdiindex.htm

OECD Stat. (2018). Trade in Value Added (TiVA): Principal Indicators. Dataset. Paris: OECD Stat, December. https://stats.oecd.org/Index.aspx?datasetcode=TIVA_2018_C1\#

Owen, E. (2013). Unionization and Restrictions on Foreign Direct Investment. International Interactions, 39(5), 723-747.

Owen, E. (2015). The Political Power of Organized Labor and the Politics of Foreign Direct Investment in Developed Democracies. Comparative Political Studies, 48(13), 1746-1780.

Pandya, S. S. (2010). Labor Markets and the Demand for Foreign Direct Investment. International Organization, 64(3), 389-409.

Pandya, S. S. (2014). Democratization and Foreign Direct Investment Liberalization, 1970-2000. International Studies Quarterly, 58(3), 475-488.

Pandya, S. S. (2016). Political Economy of Foreign Direct Investment: Globalized Production in the Twenty-First Century. Annual Review of Political Science, 19(1), 455-475.

Peker, E. (2018). "EU to Step Up Review of Foreign Investments." Wall Street Journal, November 20. https://www.wsj.com/articles/eu-to-step-up-review-of-foreign-investments-1542742945

Pinto, P. M., \& Pinto, S. M. (2008). The Politics of Investment Partisanship: And the Sectoral Allocation of Foreign Direct Investment. Economics \& Politics, 20(2), 216-254.

Raess, D. (2020). “The Demand-Side Politics of China's Global Buying Spree: Managers' Attitudes toward Chinese Inward FDI Flows in Comparative Perspective." Review of International Political Economy (July 7).

Roberts, A., Moraes, H. C., \& Ferguson, V. (2019). Toward a Geoeconomic Order in International Trade and Investment. Journal of International Economic Law, 22(4), 655-676.

Romer, P. (1993). Idea Gaps and Object Gaps in Economic Development. Journal of Monetary Economics, 32(3), 543-573.

Scheve, K., \& Slaughter, M. J. (2004). Economic Insecurity and the Globalization of Production. American Journal of Political Science, 48(4), 662-674.

Schill, S. W. (2019). The European Union's Foreign Direct Investment Screening Paradox: Tightening Inward Investment Control to Further External Investment Liberalization. Legal Issues of Economic Integration, 46(2), 105-128.

Servan-Schreiber, J. J. (1968). The American challenge. Translated by R. Steel. Atheneum.

Tang, S., Selvanathan, E. A., \& Selvanathan, S. (2008). Foreign Direct Investment, Domestic Investment and Economic Growth in China: A Time Series Analysis. The World Economy, 31(10), 1292-1309.

Taylor, K., \& Driffield, N. (2005). Wage Inequality and the Role of Multinationals: Evidence from UK Panel Data. Labour Economics, 12(2), 223-249.

Tingley, D., Christopher, Xu., Chilton, A., \& Milner, H. V. (2015). The Political Economy of Inward FDI: Opposition to Chinese Mergers and Acquisitions. The Chinese Journal of International Politics, 8(1), 27-57. 
Tsang, A. (2016). "Midea of China Moves a Step Closer to Takeover of Kuka of Germany." New York Times, July 4. https:/www.nytimes.com/2016/07/05/business/dealbook/germany-china-midea-kukatechnology-robotics.html

UNCTAD. (2020). Global Investment Flows Flat in 2019, Moderate Increase Expected in 2020. Press release. Geneva: United Nations Conference on Trade and Development, January 20. https://unctad. org/en/pages/newsdetails.aspx? OriginalVersionID $=2274$

Valero, J. (2017). “Leaders Tone down Macron's Call for Foreign Investment Scrutiny.” Euractiv, June 23. https://www.euractiv.com/section/economy-jobs/news/leaders-tone-down-macrons-call-for-foreigninvestment-scrutiny/

Valero, J. (2019). "Europe Strengthens Monitoring of Foreign Investment." Euractiv, February 14. https://www.euractiv.com/section/economy-jobs/news/europe-strengthens-monitoring-of-foreigninvestment/

Wei, K., Yao, S., \& Liu, A. (2009). Foreign Direct Investment and Regional Inequality in China. Review of Development Economics, 13(4), 778-791.

Wellhausen, R. L. (2014). The Shield of Nationality: When Governments Break Contracts with Foreign Firms. Cambridge University Press.

World Bank. (2019). World Development Indicators. Dataset. Washington, DC: The World Bank Group, December 20. https://databank.worldbank.org/source/world-development-indicators

Wübbeke, J., Meissner, M., Zenglein, M. J., Ives, J., \& Conrad, B. (2016). Made in China 2025: The Making of a High-Tech Superpower and Consequences for Industrial Countries. Berlin: Mercator Institute for China Studies, December. https://merics.org/sites/default/files/2020-04/Made\%20in\% 20China\%202025.pdf

Zeng, K. (2019). The Political Economy of Chinese Outward Foreign Direct Investment in 'One-Belt, One-Road (OBOR)' Countries. In J. Chaisse (Ed.), China's International Investment Strategy: Bilateral, Regional, and Global Law and Policy (pp. 360-384). Oxford University Press.

Publisher's Note Springer Nature remains neutral with regard to jurisdictional claims in published maps and institutional affiliations.

\section{Authors and Affiliations}

\section{Zenobia T. Chan ${ }^{1}$ (D) . Sophie Meunier ${ }^{2}$}

Sophie Meunier

smeunier@princeton.edu

1 Department of Politics, Princeton University, Fisher Hall, Princeton, NJ 08544-1012, USA

2 School of Public and International Affairs, Princeton University, Roberson Hall, Princeton, NJ 08544-1013, USA 